\title{
TRANSLATION STRATEGY IN TOBA DREAM MOVIE SUBTITLE
}

\author{
By: \\ Elisa Betty Manullang ${ }^{1)}$ \\ Gabe Hartina Marpaung ${ }^{2)}$ \\ State University of Medan \\ Willem Iskandar St, Psr V Medan Estate \\ E-mail: \\ elisamanullang@gmail.com ${ }^{1)}$ \\ hartinamarpaung1101@gmail.com ${ }^{2)}$
}

\begin{abstract}
The article deals with the translation strategies used in Toba Dream Movie. The objectives of this study were to find out types and most dominant type of translation strategies used in the subtitles of Toba Dream movie. The study was conducting by using descriptive qualitative method. The data of the study were words, phrases, and clauses in the subtitle of Toba Dream movie, there were 425 dialogues in the movie. The data analysis were taken by listing and tabulating the data. The data were analyzed based on the theory that proposed by Henrik Gottlieb. The findings inducted that there were ten types of translation strategies used in the movie, they were there were (319 times)used transfer strategy, (37 times) used paraphrase, (27 times) used dislocation, (20 times)used resignation, (10times) used expansion, (5 times)used decimation, (4 times) utterances which used condesation, (1time) used imitation, (1time) used transcription and (1time) used deletion. The dominant strategy used in the subtitles of Toba Dream movie was transfer strategy where the translator translated the dialogues completely and correctly.
\end{abstract}

Keywords: movie, subtitle, translation strategy.

\begin{abstract}
ABSTRAK
Artikel ini berhuungan dengan kajian strategi penerjemahan yang digunakan pada sebuah film yang ada di Tanah Batak berjudul Toba Dream.Tujuan dr artkel ini untuk menemukan jenis-jenis strategi penerjemahan dan juga jenis strategi penerjemahan yg paling banyak terjadi yang terdapat di film Toba Dream.Artikel ini menggunakan metode deskriptif Qualitative. Data-datanya adalah kata, frasa, dan klausa yang ada pada fim Toba Dream. Ada sebanyak 425 dialog pada film tersebut. Penganalisaan datanya diambil dengan cara mendata dengan mendaftarkan dan mentabulasikan data. Lalu data dianalisa berdasarkan teori yang dikemukakan oleh Henri Gottlich. Data yang ditemukan ada sebanyak sepuluh jenis strategi penerjemahan yang digunakan pada film tersebut. Mereka adalah
\end{abstract}


(319 kali) menggunakan transfer strategy, menggunakan praphrase 37 kali, menggunakan dislocation 27 kali, menggunakan resignation 20 kali, menggunakan expansion 10 kali, menggunakan decination 5 kali, menggunakan utterances condecation 4 kali, menggunakan imitation 1 kali, menggunakan transcription 1 kali, dan menggunakan deletion 1 kali. Strategi penerjemahan yang paling dominant yang digunakan pada film Toba Dream ini adalah Strategy Transfer yang mana penerjemah menerjemahkannya kedalam bentuk dialoq yang sempurna dan benar.

Kata Kunci: film, judul, strategi penerjemahan.

\section{PRELIMINARY}

Language is a central part of Interaction and communication. It is something we need everyday to communicate with the others. language is also tool to connect each other. Kramsch (1998: 3) state that "Language is the principle means whereby we conduct our lives." When it is used in contexts of communication, it is bound with culture in multiple and complex ways. As an example of the aplication of Kramsch's defenition about language; for instance, some international events which are broadcasted on television, internet or newspaper needs language as the medium to communicate the message or information as well as possible. Therefore, we cannot deny the existence of the language which occurs in our social lives.

In this world there is so many different languages. Expecially in Indonesia.Indonesia has many diverse cultures. Basically, every culture has their own cultural values that define the way of life for a group or society. And also language plays a great part in our life (Bloomfield, 2005;3). Without the language people will find difficulties to communicate and express their ideas, though and wishes (Yudha,2013:3).
Each nation or ever ethnic group was hasit own language. To make people easier to communicate with people from other nation and other culture, translation plays the more important role. Translation deals with languages, words or text changing the one language in to other language. Newmark (1998:10) state that translation is used to transmit knowledge , understanding and culture between groups and nations. Hatim and Munday (2004:6) define translation as " the procces of transfering a written text from source language to target language". In general, the purpose of translation is to reproduce various kinds of texts including religious, literary, scientific, and philosophical texts in another language and thus making them available to wider readers. The present paper aims at scrutinizing whether there exists any point of strategies and to identify which of these strategies seem to be more effective than the others.

According to Reich (2006:7), translation can be separated in to two types: literary translation and audiovisual translation (AVT). Literaty translation is translating written text in a literary language, it can be found in book or novel. Meanshile audio visual translation 
(AVT) is transferring written text from one language to another of the verbal components contained in aoudio visual works and product, it can be found in television proggram and movie.

Audio Visual Translation (AVT) is conventionally categorized into subtittling and dubbing. Each of them interfered with the original text to different extent. Basically , dubbbing is refered to any technique of covering the original voice in an audio visual production by other voice. On the other hand, the activity of subtitling is the process of translation where one language are as source language is transfered into other language as the target language. Subtitling textual version of dialagues which are not in film or movie only, but also in television programs. Subtitling is very important in film and movie, because it has many contribution and to ignore the misunderstanting to the people who don't understanding the language. There are usually displayed at the bottom of the screen to make people easy to read it. Through subtitling, the audience of the foreign film or movie can enjoy the film or the movie by reading the translated text on the buttom of the screen without having the ambiguous and misunderstanding. Subtitling is more authentic, since it does not hide the original sound. As the major methods of translating film or movie, subtitling involves the least interference with the original .In the other words, it contributes to experience the flavor of the foreign language. Subtitling is away to translate the foreign film or movie without tamparing the original soundtrack and dialogues, as is the case in dubbing.

There are so many Indonesian movies have reached the international industry. One of those movies is Toba Dream movie. The quality pictures and interesting story make the movie attract the audience from all over cicle of the netizen or people. Therefore, the movie translator must transfer Indonesian as the source language to certain target language, the movie also has contain by tobanese language, so it has a difficult way to translate it, because we must know the tobanese language also. In this case English, in order to make audience easier to understand and enjoy the film.

In this study, the author uses Toba Dream movie as the object of the study. Why the author take Toba Dream as the object, from the previous researches that we know there are some research about the subtitling of movie, but this movie is diffrent, because it contain by the culture that is tobanese culture, and the language also not only in Bahasa but also Toba language, so the people who watching it will know about the cultural language . This movie is adabted from the novel of the same title essay.

Besides, this research can give a contribution for promoting business. It can in crease the possibility to export the movie to foreign countries. And this movie is written by TB Silalahi or the full name is Lt. Gen. TNI. Dr. Tiopan Bernhard Silalahi, S.H is a former Minister of State for Administrative Reform in the VI Development Cabinet. And he Graduating from National Military Academy in 1961, 
his last position in the military was AssistantI Kasad with the rank of Major General, 1988and this movie released on april 2015, the moviehas a background about love and romantic story.

Based on the background of the study, the problems of this study are form that are the type of translation stategies used in Toba Dream Movie Subtitle and What is dominant type of translation strategies used in Toba Dream Movie Subtitle. Related to the problems above, the objectives of the study are to find out the translation strategy used in Translating subtittle of Toba Dream Movie and to find out the type of translation strategy that dominantly used in used inToba Dream Movie subtitle. The study focuses on finding the translation strategy that are used insubtittle of Toba Dream Movie. The writer took the Toba Dream Movie representative data to be analyzed. This analysis was conducted by using the theory of translation strategies proposed by Henrik Gottlieb (1992). The strategies are condensation, decimation, dislocation, expansion, imitation, paraphrase, transcription and transfer.

\section{REVIEW OF LITERATURE Translation}

Translation is a process of changing the language of the source language (SL) into target language (TL). The word "translation" etymologically is derived from the Latin translatio, which comes from trans, "across" + ferre, "to carry" or "to bring" (-latio in turn coming from latus, the past participle of ferre). If translated directly, the meaning of word translation is "a carrying across" or "a bringing across'. In scope the language, etymology can be concluded translation means "a bringing across of a text from one language to another.

\section{Audio Visual Translation (AVT) \\ Generally, Audio Visual} Translation (AVT) is similar with literary translation. Literary translation is translating written texts in a literary language. Meanwhile, audio visual translation (AVT) is translating film or television program in which the aim is to make them easily understood by the target audiences who are not familiar with the original source language. Both of those translation are used to refurmulate the message from the source language into the target and avoid any musunderstanding in the process.

\section{Types of Audiovisual Translation (AVT)}

There are many types of audiovisual translation (AVT) language transfer in which dubbing and subtitling are just two of the most relevant ones. These two common procedures of audiovisual translation (AVT) language transfer have some sub-categories; Simultaneous subtitling which use in real time for instance live performance interview .

\section{Subtitle and Subtitling}

Subtitle is written translation of original dialogue which is usually positioned toward the foot of the screen. It is one of the major types of screen translation, and can be defined 
as a written text which is incorporate with what can be heard on screen. O'Connell (2007: 169) expresses subtitle as a complement of the original soundtrack which adds the written text on the screen Subsequently, Gottlieb (2005:19) states that subtitling involves more than one semiotic system. Tradition is a specialty in the tradition of an ethnic including around Lake Toba Lubis M (2020), Hernawati H \& Pura N (2020).

\section{Strategies of Translation}

Translating strategies are strategies that are used in making subtitles. It is when a translator encounters a problem while translating a text. According to Gotlieb (as cited in Ghaemi\& Benyamin, 2010: 42) there are ten translating strategies to make subtitles movie, namely : expansion, paraphrase, transfer, transcription, dislocation, condensation, decimation, deletion, and resignation.

\section{RESEARCH METHOD}

This researcher was conducted by using descriptive qualitative method. Firstly, describtive reseach is designed to obtain the information concering the status of the phenomena. It is directed to

\section{RESULTS AND DISCUSSION}

After analyzing all of the data for the types of translation strategies in Toba Dream movie, there were two research findings found based on the problems of the study. The determine the nature of a situation, as it exists at the time of investigation. The source of the data is the subtitle of Toba Dream movie. The data of this research is the transcriptionof TobaDream Movie, both of English and Indonesia. The step of collecting data in this research were reading the script several times both language, in English and Indonesia. Transcribing both language in to table as the data. After collecting all the data by using the techique, they are analyzed by using ten strategies of translating explained by Gottlieb then clasified by apllying the following steps :

1. Identifiying each sentences in both language, English and Bahasa, by using strategies used in translating the sentences.

2. Clasifiying and listing the data into the types of translation strategies.

3. Tabulating and total number of each type of translation strategies.

4. Determining and describing the most dominant type of translation strategy found in the Toba Dream Movie.

5. Finding the percentage from each type of translation strategies found in the Toba Dream Movie Subtitile. research findings were presented as follows :

1.There were ten kind of translation strategies that were found in Toba Dream movie. They were transfer, paraphrase, dislocation, resignation,expansion, decimation, 
condesation, imitation, transcription and deletion.

2.Transfer was the most strategies used in the movie, it was applied 319 times. The second-mostly used strategy was paraphrase that was used 37 times. In the third rank, there was dislocation with the use of 27 times. Then followed by resignation (20 times), expansion (10 times), decimation (5 times), condensation (4 times), the least used strategy was and the least-used strategy was imitation, transcription, and deletion that was applied one time.

\section{DISCUSSION}

In discussion, the researcher describes the reasons of findings about the answers of research problems. The first research problem focused on with kinds of translating strategy found in Toba Dreammovie.

Subtitle is translation from one language to another language of dialogue spoken by the actors in the film which usually positioned in the bottom of the screen. Subtitle can facilitate the audience when watching a movie in a foreign language. That is why, translator or subtitler have to use strategies in translating the movie to make the audience easier to understand. According to the theory of Henrik Gottlieb (1992) there are ten strategies that can be used in translating a movie subtitle, they are: expansion, paraphrase, transfer, transcription, dislocation, imitation, condensation, decimation, deletion, and resignation.

In fact, in the movie the translator or subtitler use all of the types of translation strategies in the subtitle. Even the dominant type of translation strategy in the Toba Dream Movie subtitles is trasfer strategy and some of them, the kind of traslation strategy only use one time in the dialogue.

There are 319 utterances that used transfer strategy, 37 utterances used paraphrase strategy, 27 utterances used dislocation strategy, 20 utterances used resignation strategy, 10utterances used expansion strategy, 5 utterances used decimation strategy, 4 utterances used condensationstrategy, 1 utterance used imitation, transcription and deletion.

This findings had some similarities with the studies in relevant studies that had been discussed before, where the previous researchers also only found some from the ten strategies. The second problem in this study is focused on which type of translation strategies mostly used in the subtitle of Toba Dream movie. To answer this question, the researcher counted the frequency of each translating strategy inToba Dream movie. The dominant type of translation strategy in the Toba Dream Movie subtitles is transfer strategy was used 319 times with the percentages is $75.05 \%$.

Transfer strategy was used 319 times $(75.05 \%)$. The percentage indicates that this strategy used for 319 times by the translator or subtitler to translate the subtitle from Bahasa Indonesia into English subtitle in the movie. Paraphrase strategy was used 37 times or $(8.70 \%)$. Dislocation strategy was used 27 times or(6.35\%). Resignation strategy was used by 20 times or( $4.70 \%)$. Expansion strategy was used 10 times $(2.35 \%)$. 
Decimation strategy was used 5 times or $\quad(1.17 \%)$. Condensationstrategy was used 4 times $(0.94 \%)$.Imitation strategy was This strategy is used by maintaining the source text as accurately possible into the target text. Besides, it was discovered that this strategy was used if the dialogues were shortlength dialogues or medium-length dialogues. The most possible reason why in this movie transfer strategy got the mostly-used strategy is because the translator aimed to make the translation as equivalent as medium-length the original and the movie has much of short-length and dialogues. In this discussion, it can be seen that theory really worked in reality. But, there were some reason that caused the translator did not use all the types of the strategies, such as the effort of the translator and the length of the dialogues in the movie subtitle.

\section{CONCLUSIONS AND SUGGESTIONS}

1. There were ten kinds of translation strategies which found in Toba Dream movie with the total number was 425 . There were 319 utterances which used transfer strategy 37 utterances which used paraphrase, 27 utterances which used dislocation, 20 utterances which used resignation, 10 utterances which used expantion, 5 utterances which used decimation, 4 utterances which used condensation, and 1 utterance which used imitation, transcription and deletion.

2. The analysis of the translation showed that among all of the translation strategies, transfer strategy was the most frequently used strategy, which was applied 319 times. This strategy is used by maintaining the source text as accurately possible into the target text. It was discovered that this strategy was used if the dialogues were short-length dialogues or medium-length dialogues. This is why in this movie transfer strategy got the mostly-used strategy because this movie has much of short-length and medium-length dialogue.

\section{SUGGESTIONS}

1. For Translators or Subtitlers .Translation strategies are needed to translate one language into another language. The subtitler can just use one of the strategies to translate the sentence if it is possible. However, they can use more than one strategy in translating subtitle if it is needed. We have to do some strategies to make the translation become natural, communicative, and easily understandable by the readers. Besides, the result of the translation should have the same meaning from the source language to the target language.

2. For English Department Students who are interested in translation that they have to know better the meaning and the culture of the source language as well as the target language when they have to analyze the subtitle.

3. For the next researchers who have the same interest translation studies can make the next .The researcher hopes that the results of this study researchers who take 
the same field of research as the reference that might be relevant to their researches and conduct their further studies because it can be used to analyze a movie.

\section{REFERENCES}

Bell,T Roger .1991. translation and translating : theory and practice oftranslation.london ; longman

Bloomfield,

Leonard.2005.Language. New Delhi : Byjainendra Prakash Jain AT Shri Jainendra Press.

Ghaemi, F.\& Benyamin, J.2010.Strategy Used in the Translation of Interlingual Subtitiling. Journal of English Studies, Volume 1.(pages 3949) Retreived from: www.sid.ir/En?VEWSSID/J_p df/1024220100103.pdf

Gottlieb. H. 1992. Subtitling A New University Discipline. In Dollerup, C. \&Loddegaard, A. Teaching Translation and Interpreting: $\quad$ Training. Talentand Experience. Amsterdam: John Benjamin

Hatim, B \& Munday, J. 2004 . Translation and advanced resource book . London: Routledge

Kramsch , c.1998. language and culture .Oxford: Oxforrd UP

Liangqiu,Lyu \& Wang Dong Hui.2018.A Study of Subtitle Translation from the Prespective of Skopos Theory :Youth Film as a case study.School of Foreign Language,North China Electric
PowerUniversity,

Beijing,China: Published

Mantari Anisa.2016.Translation Strategies of Slang Expression in Spy Movie Newmark,P.(1988a). A Text book of Translation. Hertfordshire: Prentice HallReich ,P 2006 the film and the book in translation ( master's diploma thesis, Masaryk

Yudha,D.W.2013. Translation Methods Used in Three Chapters of "TANJUNG MAS SEBAGAI CENTRAL POINT PORT" Handbook. Unpublished Paper. Semarang: UNIDUS.

Lubis, M. (2020). REVITALISASI NILAI-NILAI KEARIFAN LOKAL MASYARAKAT HUKUM ADAT BATAK TOBA DALAM MELINDUNGI EKSISTENSI DANAU TOBA DI MATA DUNIA (KAJIAN HUKUM PROGRESIF). Jurnal Darma Agung, 27(3), 1234-1244. doi:10.46930/ojsuda.v27i3.607

Hernawaty, H., \& Purba, N. (2019). ETNOGRAFI KOMUNIKASI PADA MASYARAKAT BATAK TOBA DI KABUPATEN SAMOSIR PROVINSI SUMATERA UTARA MENGENAI ANALISIS TINDAK TUTUR DALAM UPACARA KEMATIAN SAURMATUA. Jurnal Darma Agung, 27(3), 1159-1172.

doi:10.46930/ojsuda.v27i3.376 